\title{
Borage Aromatic Water as a Medicinal Drink: Chemical Composition Analysis of Different Populations in the Local Markets of Iran
}

\author{
Azadeh Shiati ${ }^{1,2}$, Mahmoodreza Moein ${ }^{1,2}$ (D) , Amirhossein Sakhteman ${ }^{3}$ (D) , Ehsan Amiri-Ardekani ${ }^{4,5,6}$ (D) \\ Mohammad M. Zarshenas 1,4,* (D) \\ Medicinal Plants Processing Research Center, Shiraz University of Medical Sciences, Shiraz, Iran \\ 2 Department of Pharmacognosy, School of Pharmacy, Shiraz University of Medical Sciences, Shiraz, Iran \\ 3 Department of Medicinal Chemistry, School of Pharmacy, Shiraz University of Medical Sciences, Shiraz, Iran \\ 4 Department of Phytopharmaceuticals (Traditional Pharmacy), School of Pharmacy, Shiraz University of Medical Sciences, \\ Shiraz, Iran \\ 5 Student Research Committee, Shiraz University of Medical Sciences, Shiraz, Iran \\ 6 Student Association of Indigenous Knowledge, Shiraz University of Medical Sciences, Shiraz, Iran \\ * Correspondence: Zarm@sums.ac.ir;
}

Received: 20.12.2020; Revised: 10.01.2021; Accepted: 12.01.2021; Published: 20.01.2021

\begin{abstract}
Borage hydrosol has nutritional and medicinal benefits. Due to this hydrosol's widespread consumption, it is worthy of achieving a simple and reliable method to assess their quality. The present study evaluated ten market samples of Borage hydrosol in Fars province to determine their quality. Also, the hydrosol of a collected Borage was prepared in the lab to serve as a standard sample. Essential oils from hydrosols were yielded via liquid-liquid extraction procedure, injected into a gas chromatograph (GC), and respective compounds were identified. High-performance thin-layer chromatography (HPTLC), pH, and electrical conductivity were also analyzed. Results showed transCaryophyllene as the major compound in the standard sample and also in four of ten samples. Moreover, Cembrene A was found as the major ingredient in seven samples. Delta-Cadinol was one of the prominent constituents in three samples and also in the standard. Di-butyl phthalate, Thymol, and Carvacrol were found in some samples due to the poor quality of the container or the migration of monomers from the container's inner side into the hydrosol low-quality solvent. Essential oil extraction and identification with the mentioned method can be introduced as a simple quality control procedure. This study can be considered to identify and analyze volatile constituents in hydrosols distributed in the market.
\end{abstract}

Keywords: borage; essential oil; hydrosol; distillation; GC-MS; HPTLC.

(C) 2020 by the authors. This article is an open-access article distributed under the terms and conditions of the Creative Commons Attribution (CC BY) license (https://creativecommons.org/licenses/by/4.0/).

\section{Introduction}

Herbal distillates are known as aromatic liquid formulations generally yielded via steam or water distillation of herbal aromatic fractions and botanical parts [1, 2]. During the distillation procedure, fractions of essential oil may migrate into the aqueous phase and produce aromatic water [3-5]. Distillates are produced during the extraction of essential oils and are often known as a byproduct. Even so, there are numerous medical, nutritional, and cosmetic applications for these preparations [6-11]. 
Borage distillate is a medicinal drink commonly produced from aerial parts of related medicinal herbs [12]. Iranian borage or Echium amoenum Fisch. \& C.A.Mey. is traditionally applied as cardiotonic, diaphoretic, tranquilizer, and diuretic in Persian folk medicine [13-17]. Less famous borage, Anchusa italica Retz. is also used as a medicinal herb with therapeutical aspects similar to E. amoenum. They are mainly used to manage flu and symptoms of the common cold in folk medicine [13]. Recent research have evaluated their effect on fertility [18], cerebral ischemia [19], premenstrual syndrome [20], Alzheimer [21], major depressive disorder [22], and anxiety [23].

Although these medicinal plants are extensively used in folk and traditional medicine, there is a concern about the safety of their preparations [24, 25]. According to some reports like Avila et al. study, no hazardous outcomes have been observed regarding pyrrolizidine alkaloids of Borago officinalis L., the official species, on the liver and its biochemical parameters. However, parallel studies have reported the hepatotoxicity of some isolated pyrrolizidine alkaloids from E. amoenum [26-29]. The possibility of the presence of toxic ingredients in some common preparations of Iranian borage should also be considered. Accordingly, the current study aimed to analyze and investigate the volatile constituents, thin layer chromatographic fingerprint, $\mathrm{pH}$, and conductivity of 10 samples of borage distillates, as a familiar medicinal drink in Iran to present a report and to introduce some phytochemical criteria which can be useful in the selection of samples with better quality.

\section{Materials and Methods}

\subsection{Sample preparation.}

Ten borage distillates were purchased from the apothecaries of Fars province (south of Iran). These distillates were numbered from one to ten. Then, two different borage samples, $A$. italica and, E. amoenum were prepared, botanically authenticated, and subjected to hydrodistillation to yield the respective distillates. All samples were kept in the fridge $\left(4^{\circ} \mathrm{C}\right)$ for further steps. The yielded distillates and respective essential oil from A. italica (voucher no. PM-1083) and, E. amoenum (voucher no. PM-1084) samples were numbered as 11 and 12. The herbariums were authenticated by the Department of Phytopharmaceuticals, Faculty of Pharmacy, Shiraz University of Medical Sciences, Iran.

\subsection{Essential oil recovery and concentration.}

By using a liquid extraction apparatus, volatile oil fractions of samples were recovered. Briefly, $500 \mathrm{ml}$ of each sample was mixed with an equal volume of petroleum ether (Merck, Germany). The mixture was heated up to $45^{\circ} \mathrm{C}$ for about $150 \mathrm{~min}$ to recover the essential oil. Following extraction of the petroleum ether phase, fresh petroleum ether $(500 \mathrm{ml})$ was added to the system to increase the organic phase's respective essential oil yield. The mixture was subsequently heated for around $150 \mathrm{~min}$. The recovered essential oil of each borage distillate sample was individually concentrated by a vacuum pump-connected rotary evaporator. All organic phases were kept in amber glass vials for further analysis.

\subsection{Gas chromatography $(G C)$ and analysis of yielded constituents.}

A gas chromatograph (Agilent Technologies 7890A) apparatus connected to a flame ionization detector (FID) and equipped with an HP-5 column $(25 \mathrm{~m}$ length $\times 0.32 \mathrm{~mm}$ i.d.; film 
thickness $0.52 \mu \mathrm{m}$ ) was employed for adjusting a method of analysis. The carrier gas was Nitrogen, and the related flow rate was $1 \mathrm{ml} / \mathrm{min}$ (split ratio: 1:30). The injector and detector temperature values were adjusted at $250^{\circ} \mathrm{C}$ and $280^{\circ} \mathrm{C}$, respectively. The temperature of the GC column was linearly programmed from $60^{\circ} \mathrm{C}$ to $250^{\circ} \mathrm{C}$ (increased $5^{\circ} \mathrm{C} / \mathrm{min}$ ) and subsequently was held at $250^{\circ} \mathrm{C}$ for $10 \mathrm{~min}$.

The above method and condition were considered for identification of the volatile constituents in a gas chromatograph (Agilent Technologies 7890A) connected to a mass detector (Agilent technologies model 5975C) and equipped with an HP-5MS capillary column (phenylmethyl siloxane coated, $30 \mathrm{~m} \times 0.25 \mathrm{~mm}$ i.d.). Carrier gas in this GC/MS system was Helium with an adjusted flow rate of $1 \mathrm{ml} / \mathrm{min}$. The interface temperature was set at $280^{\circ} \mathrm{C}$. The mass spectrometer was acquired in EI mode $(70 \mathrm{eV}$; mass range: $30-600 \mathrm{~m} / \mathrm{z})$.

Before injecting the volatile extracted samples of borage distillate, a series of normal alkanes (C8-C30) was injected to GC/MS to fulfill the determination process of the component identification via calculating the Kovats indices (KI). Identification of components was based on comparing their mass spectra with Willey (n17), libraries of spectra (Adams'), and those cited in related literature.

MATLAB software (MATLAB 8.6, Release 2015b, The MathWorks, Inc.) was used to analyze the results obtained from the essential oil samples in the GC / MS method and accurately evaluate their compositions draw Hierarchical Cluster Analysis (HCA) diagrams.

\subsection{Determination of $p H$ and conductivity.}

Each borage distillate sample was subjected to $\mathrm{pH}$ and conductivity evaluation via a $\mathrm{pH}$ meter (Crison) and a bench-top conductivity meter instrument (AZ-86505), respectively. All measurements were carried out in triplicate, and derived data were presented as "Mean \pm SD".

\subsection{High-performance thin-layer chromatography (HPTLC) fingerprinting.}

The HPTLC fingerprinting for extracted essential oils from distillates was carried out using a CAMAG system of TLC fitted with winCATS (version 1.2.3) software. To perform the TLC, concentrated essential oil samples were diluted in dichloromethane (1:4), and $2 \mu \mathrm{L}$ of those were sprayed on a silica gel plate $60 \mathrm{~F} 254(10 \times 20 \mathrm{~cm}$, Merck, Germany). The TLCs of samples were developed in a mobile phase containing Toluene (Merck, Germany); Ethyl acetate (Merck, Germany) (90:10). Chromatographic bands were first visualized with ultraviolet lamps at $254 \mathrm{~nm}$ and $365 \mathrm{~nm}$ and subsequently with anisaldehyde-sulfuric acid (Merck, Germany). This fingerprint was carried out for all purchased hydrosols.

\section{Results and Discussion}

This study includes the quality assessment of ten selected samples of borage aromatic water available in the Fars province. For this purpose, the essential oil of each of the samples was extracted and concentrated by the liquid-liquid extraction method, and their compounds were identified. Liquid-liquid extraction is one of the most common methods for extracting volatile compounds from plant extracts [30, 31]. However, this method has disadvantages such as loss of some volatile compounds, low efficiency, and possible degradation of some unsaturated chemical compounds due to high temperature [32, 33]. However, this method is still used to be organic solvent-free, ease of operation, and cost-effective $[34,35]$. In this study, this method was used to extract borage essential oil. 
Following analysis of recovered essential oil samples, 58 different constituents have been identified based on the "Identification of Essential Oil Components by Gas Chromatography/Mass Spectrometry" textbook [36] and useful websites, e.g., http://webbook.nist.gov [37] and https://www.pherobase.com/ [38] (Table 1). Only identification in two samples were more than $90 \%$ of the constituents. However, in one sample, the identification of $50 \%$ of the volatile compounds could not be carried out (S5).

Table 1. Chemical composition of the essential oils from hydrosol samples.

\begin{tabular}{|c|c|c|c|c|c|c|c|c|c|c|c|c|c|}
\hline No. & Component & $\mathbf{S}_{1}$ & $\mathbf{S}_{2}$ & $\mathbf{S}_{3}$ & $\mathbf{S}_{4}$ & $\mathbf{S}_{5}$ & $\mathbf{S}_{6}$ & $\mathbf{S}_{7}$ & $\mathbf{S}_{8}$ & $\mathbf{S}_{9}$ & $S_{10}$ & $\mathbf{S}_{\mathrm{STD}}$ & $\mathbf{K I}_{\mathbf{C A L}}$ \\
\hline 1 & $\alpha$-Thujene & 0.43 & - & - & - & - & - & - & - & 0.17 & - & - & 932 \\
\hline 2 & $\alpha$-Pinene & 4.56 & 2.40 & 1.13 & 0.79 & - & 3.37 & 6.60 & 1.40 & 2.20 & - & 4.97 & 940 \\
\hline 3 & Sabinene & 1.52 & - & 0.39 & - & - & - & 0.56 & 0.65 & 0.13 & - & - & 977 \\
\hline 4 & $\beta$-Pinene & 0.70 & - & 0.16 & - & - & - & 0.54 & 2.24 & 0.21 & - & 0.53 & 981 \\
\hline 5 & $\beta$-Myrcene & 0.52 & - & 0.45 & 1.15 & - & 0.54 & 1.65 & - & - & - & - & 993 \\
\hline 6 & Octanal & - & - & 0.17 & 1.00 & - & - & - & - & - & - & - & 1004 \\
\hline 7 & $\delta$ 3-Carene & 0.79 & - & 0.22 & - & - & - & - & - & 0.46 & - & 1.30 & 1014 \\
\hline 8 & $\alpha$-Terpinene & 0.24 & - & - & - & - & - & - & - & - & - & - & 1019 \\
\hline 9 & o-Cymene & 0.24 & - & - & - & - & - & - & - & 0.17 & - & - & 1027 \\
\hline 10 & Limonene & 2.93 & - & 1.02 & - & - & 0.51 & 1.29 & 1.80 & 1.27 & - & - & 1031 \\
\hline 11 & $\gamma$-Terpinene & 0.42 & - & 0.19 & - & - & - & - & - & 0.18 & - & 0.27 & 1061 \\
\hline 12 & p-Tolualdehyde & - & - & 0.83 & - & 0.47 & - & - & - & - & - & - & 1069 \\
\hline 13 & Methylbenzaldehyde & 0.5 & - & - & 2.31 & - & - & - & - & 0.20 & - & 0.32 & 1070 \\
\hline 14 & $\alpha$-Terpinolene & 0.19 & - & 0.20 & 0.94 & - & - & - & - & - & - & - & 1088 \\
\hline 15 & Linalool & 0.29 & - & 0.54 & 1.76 & - & - & - & - & - & - & - & 1101 \\
\hline 16 & Menthol & 3.01 & - & - & - & - & - & - & - & - & - & - & 1172 \\
\hline 17 & Terpinen-4-ol & 0.18 & - & 0.21 & - & - & - & - & - & - & - & - & 1180 \\
\hline 18 & Methyl veratrol & - & - & - & - & - & - & - & - & - & 0.55 & - & 1230 \\
\hline 19 & Nonanoic acid & - & - & 0.21 & 1.91 & - & 0.42 & - & - & - & - & - & 1268 \\
\hline 20 & Cinnamaldehyde & - & - & - & - & - & - & - & - & - & 2.34 & - & 1272 \\
\hline 21 & Anethole & - & - & - & 1.13 & - & - & - & - & - & - & - & 1287 \\
\hline 22 & Thymol & - & - & - & 1.01 & 0.45 & 0.91 & 0.63 & - & - & 9.13 & - & 1291 \\
\hline 23 & Carvacrol & - & - & - & - & 0.46 & 0.43 & - & - & - & 21.46 & - & 1301 \\
\hline 24 & 4-Vinylguaiacol & - & - & - & - & - & - & - & - & - & 2.03 & - & 1315 \\
\hline 25 & $\Delta$-Elemene & - & - & - & - & - & - & - & - & 0.63 & - & 0.77 & 1340 \\
\hline 26 & $\alpha$-Cubebene & 0.39 & - & 0.28 & - & - & - & - & 0.57 & 1.53 & - & 0.39 & 1353 \\
\hline 27 & Eugenol & - & - & - & - & - & - & 0.53 & - & 0.81 & - & - & 1359 \\
\hline 28 & 3-dodecenal & - & - & - & 2.01 & 0.67 & - & - & - & - & - & - & 1364 \\
\hline 29 & Isoledene & 1.64 & - & 0.51 & - & - & - & - & - & 0.78 & - & 0.85 & 1370 \\
\hline 30 & $\beta$-bourbonene & 0.92 & - & - & - & - & - & - & - & 1.01 & - & 1.11 & 1374 \\
\hline 31 & $\alpha$-Copaene & 5.73 & - & 4.22 & 1.00 & - & - & 0.67 & - & 9.05 & - & 5.16 & 1381 \\
\hline 32 & $\beta$-Elemene & 2.20 & - & 1.69 & - & - & 0.66 & 1.08 & 0.92 & 2.71 & - & 1.72 & 1396 \\
\hline 33 & $\alpha$-Gurjunene & 0.45 & - & 0.88 & - & - & - & - & - & 0.24 & - & 0.45 & 1415 \\
\hline 34 & trans-Caryophyllene & 15.50 & 1.18 & 12.16 & 3.06 & 0.43 & 2.27 & 5.08 & 4.51 & 9.93 & - & 23.28 & 1428 \\
\hline 35 & Aromadendrene & 0.43 & - & - & - & - & - & - & - & 0.54 & - & 0.43 & 1444 \\
\hline 36 & $\alpha$-Humulene & 3.75 & 0.91 & 3.00 & 0.98 & - & 1.53 & 1.80 & 3.97 & 7.42 & - & 4.46 & 1460 \\
\hline 37 & allo-9-aromadendrene & 2.32 & - & - & - & - & - & - & - & 1.51 & - & 2.33 & 1468 \\
\hline 38 & Curcumene & 1.24 & - & - & 1.01 & - & - & - & 0.63 & 4.06 & - & 3.05 & 1485 \\
\hline 39 & $\beta$-Selinene & 1.93 & - & 1.52 & - & - & - & - & - & 3.33 & - & 1.89 & 1492 \\
\hline 40 & $\alpha$-Selinene & 2.68 & - & 2.22 & 0.77 & 2.12 & - & - & - & 3.80 & - & 2.66 & 1501 \\
\hline 41 & $\alpha$-Muurolene & 1.09 & - & 0.95 & - & - & - & - & - & 1.04 & - & 1.33 & 1505 \\
\hline 42 & $\beta$-Cadinene & - & - & 7.07 & 0.67 & - & - & - & 0.62 & 2.40 & - & 7.08 & 1520 \\
\hline 43 & Cadina-1(2),4-diene & - & - & - & - & - & - & - & - & 0.16 & - & - & 1527 \\
\hline 44 & $\Delta$-Cadinene & 8.75 & - & 7.25 & 1.34 & - & - & 0.94 & 0.66 & 11.44 & - & 7.59 & 1530 \\
\hline 45 & $\alpha$-Cadinene & 0.61 & - & 0.53 & - & - & - & - & - & 0.20 & - & 0.60 & 1542 \\
\hline 46 & Germacrene B & 0.39 & - & 0.38 & - & 0.65 & - & - & - & 0.41 & - & 0.27 & 1563 \\
\hline 47 & Caryophyllene oxide & 1.12 & 3.29 & 1.19 & 1.26 & 0.51 & 2.49 & 2.67 & 1.86 & 1.09 & - & 1.38 & 1590 \\
\hline 48 & $\alpha$-Cadinol & 12.38 & - & 15.70 & - & 0.48 & 0.93 & 1.14 & 1.74 & 2.16 & - & 11.18 & 1648 \\
\hline 49 & $\beta$-Eudesmol & 0.35 & 0.43 & 0.47 & - & - & - & - & - & - & - & 0.36 & 1656 \\
\hline 50 & $\alpha$-Eudesmol & 0.33 & - & - & - & 1.68 & - & - & - & 0.57 & - & 0.43 & 1659 \\
\hline 51 & Tetradecanoic acid & - & - & - & - & 1.82 & - & - & - & - & - & - & 1760 \\
\hline 52 & Cyclohexadecane & 0.23 & - & - & - & - & - & - & - & - & - & - & 1878 \\
\hline 53 & Methyl palmitate & - & - & - & - & - & - & - & - & - & 6.10 & - & 1927 \\
\hline 54 & Cembrene & - & 4.49 & 0.47 & 5.45 & 2.62 & 2.65 & 2.55 & 2.99 & 0.57 & - & - & 1935 \\
\hline 55 & Thunbergen & - & 1.82 & 8.60 & 2.45 & . & - & 2.38 & 2.85 & 0.41 & - & - & 1949 \\
\hline
\end{tabular}




\begin{tabular}{|c|c|c|c|c|c|c|c|c|c|c|c|c|c|}
\hline No. & Component & $\mathbf{S}_{1}$ & $\mathbf{S}_{2}$ & $\mathbf{S}_{3}$ & $\mathbf{S}_{4}$ & $\mathbf{S}_{5}$ & $\mathbf{S}_{6}$ & $\mathbf{S}_{7}$ & S8 & S9 & $\mathbf{S}_{10}$ & SSTD & KI CAL \\
\hline 56 & Neocembrene A & - & 37.72 & - & 58.05 & 18.16 & 40.12 & 38.14 & 43.43 & 8.26 & - & - & 1955 \\
\hline 57 & Dibutyl phthalate & 1.15 & - & - & - & - & - & - & - & - & 53.03 & 0.32 & 1965 \\
\hline 58 & Ethyl palmitate & - & - & - & 0.68 & 0.85 & - & - & - & - & - & - & 1994 \\
\hline 59 & Thunbergol & - & 13.85 & 2.35 & 2.25 & 14.02 & 11.31 & - & 6.67 & 3.08 & - & - & 2051 \\
\hline 60 & Heneicosane & - & 1.10 & - & - & 0.41 & 0.54 & 0.66 & - & - & - & - & 2100 \\
\hline 61 & Linoleic acid & - & - & - & - & 1.99 & 1.11 & - & - & - & - & - & 2133 \\
\hline 62 & 9-Octadecenoic acid & - & - & - & - & 6.82 & 0.43 & - & - & - & - & - & 2141 \\
\hline & Identification & 82.1 & 67.19 & 77.16 & 92.98 & 47.79 & 69.79 & 68.91 & 77.51 & 84.13 & 94.64 & 86.48 & \\
\hline
\end{tabular}

In this study, data analysis shows that the highest amount of volatile constituents in most samples were sesquiterpenes. Table 2 are reported the major compounds (concentration $>5 \%$ ) and their incidence in samples.

Table 2. Major compounds of the essential oils from hydrosol samples.

\begin{tabular}{|c|c|c|c|c|c|c|c|c|c|c|c|c|c|}
\hline No. & Component & $\mathbf{S}_{1}$ & $\mathbf{S}_{2}$ & $\mathbf{S}_{3}$ & $\mathbf{S}_{4}$ & $S_{5}$ & S6 & $\mathbf{S}_{7}$ & $\mathrm{~S}_{8}$ & S9 & $\mathbf{S}_{10}$ & SSTD & Mean \\
\hline 1 & Neocembrene A & - & 37.72 & - & $\mathbf{5 8 . 0 5}$ & 18.16 & 40.12 & 38.14 & 43.43 & 8.26 & - & - & 22.17 \\
\hline 2 & trans-Caryophyllene & 15.50 & 1.18 & 12.16 & 3.06 & 0.43 & 2.27 & 5.08 & 4.51 & 9.93 & - & 23.28 & 7.04 \\
\hline 3 & Dibutyl phthalate & 1.15 & - & - & - & - & - & - & - & - & 53.03 & 0.32 & 4.95 \\
\hline 4 & Thunbergol & - & 13.85 & 2.35 & 2.25 & 14.02 & 11.31 & - & 6.67 & 3.08 & - & - & 4.86 \\
\hline 5 & $\alpha$-Cadinol & 12.38 & - & 15.70 & - & 0.48 & 0.93 & 1.14 & 1.74 & 2.16 & - & 11.18 & 4.16 \\
\hline 6 & Thymol & - & - & - & 1.01 & 0.45 & 0.91 & 0.63 & - & - & 9.13 & - & 3.83 \\
\hline 7 & $\Delta$-Cadinene & 8.75 & - & 7.25 & 1.34 & - & - & 0.94 & 0.66 & 11.44 & - & 7.59 & 3.45 \\
\hline 8 & $\alpha$-Humulene & 3.75 & 0.91 & 3.00 & 0.98 & - & 1.53 & 1.80 & 3.97 & 7.42 & - & 4.46 & 2.52 \\
\hline 9 & $\alpha$-Copaene & 5.73 & - & 4.22 & 1.00 & - & - & 0.67 & - & 9.05 & - & 5.16 & 2.34 \\
\hline 10 & $\alpha$-Pinene & 4.56 & 2.40 & 1.13 & 0.79 & - & 3.37 & 6.60 & 1.40 & 2.20 & - & 4.97 & 2.29 \\
\hline 11 & Carvacrol & - & - & - & - & 0.46 & 0.43 & - & - & - & 21.46 & - & 2.03 \\
\hline 12 & Cembrene & - & 4.49 & 0.47 & 5.45 & 2.62 & 2.65 & 2.55 & 2.99 & 0.57 & - & - & 1.98 \\
\hline 13 & Thunbergen & - & 1.82 & 8.60 & 2.45 & - & - & 2.38 & 2.85 & 0.41 & - & - & 1.68 \\
\hline 14 & $\beta$-Cadinene & - & - & 7.07 & 0.67 & - & - & - & 0.62 & 2.40 & - & 7.08 & 1.62 \\
\hline 15 & 9-Octadecenoic acid & - & - & - & - & 6.82 & 0.43 & - & - & - & - & - & 0.66 \\
\hline 16 & Methyl palmitate & - & - & - & 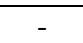 & - & - & - & - & - & 6.10 & - & 0.55 \\
\hline
\end{tabular}

Based on Table 2, in term of compounds distribution, trans-Caryophyllene was detected in ten samples, $\alpha$-Humulene, and $\alpha$-Pinene in nine samples $\alpha$-Cadinol and Cembrene in eight samples, Neocembrene A, Thunbergol and $\Delta$-Cadinene in seven samples, $\alpha$-Copaene and Thunbergen in six samples, and Thymol and $\beta$-Cadinene in five samples. Other major had less distribution in studied samples.

In term of major components concentrations mean concentration of Neocembrene A (22.17\%), trans-Caryophyllene (7.04\%), Dibutyl phthalate (4.95\%), Thunbergol $(4.86 \%), \alpha-$ Cadinol (4.16\%), Thymol (3.83\%), $\Delta$-Cadinene (3.45\%), $\alpha$-Humulene (2.52\%), $\alpha$-Copaene (2.34\%), $\alpha$-Pinene (2.29\%), Carvacrol (2.03\%), Cembrene (1.98\%), Thunbergen $(1.68 \%), \beta$ Cadinene $(1.62 \%)$, 9-Octadecenoic acid $(0.66 \%)$, Methyl palmitate $(0.55 \%)$ respectively.

Essential oils extracted from two individual samples of borage (A. italica and E. amoenum, distillate under laboratory conditions) were also injected into GC/MS and studied regarding volatile constituents. However, we could not find any volatile constituent related to E. amoenum sample by GC/MS. Finally, the profile of the essential oil A. italica distillate at the lab was considerable; this laboratory distillate was named "SLab".

SLab with a total of 29 identified constituents $(84.48 \%$ of the essential oil) contained trans-Caryophyllene in the highest amount (23.28\%). This constituent was found in samples one, three, seven, and nine too. Therapeutic effects of trans-Caryophyllene are antioxidant [3941] anti-inflammatory properties by inhibiting the cyclooxygenase enzyme [42], muscle relaxant [43], anticancer [44], neuroprotective [45, 46], antimicrobial [47], and wound healing effects [48]. 
$\alpha$-cadinol, an alcohol sesquiterpenoid, was also found in the SLab sample as $11.18 \%$ of essential oil. This combination was found in samples one and three with $12.38 \%$ and $15.70 \%$ concentrations, respectively. Different therapeutic benefits like neuroprotectice[49], hepatoprotective [50], antibacterial [51], calcium antagonistic properties [52] have been reported for $\alpha$-cadinol.

Other main components of SLab were $\Delta$-Cadinene (7.59\%) and $\beta$-Cadinene (7.08\%). There are reports of health benefits including anti-cancer [53,54], anti pneumonia [55], anti Psoroptes cuniculi effect [56], antifungal [57], and antiviral effect [54] for this compound.

Another main compound of SLab was $\alpha$-Copaene (7.08\%). Antileishmanial activity[58], antioxidant [59], and anti-cancer [60] properties are the main therapeutic uses of this compound.

Compounds such as Thymol and Carvacrol were found in five samples, indicating the presence of Thymol in processing containers or contamination in the distillation process. Dibutyl phthalate was found in some samples due to the poor quality of the container or migration of monomers from the container's inner side into the hydrosol and low-quality solvent.

According to Table 1, $47.79 \%$ to $94.64 \%$ of total compounds in samples are identified. Also, among samples, S1 is very similar to the SLab. Some of the samples have compounds such as Cembrene A and Thunbergol as major compounds. Thunbergol is macrocyclic diterpene alcohol with a fourteen-membered ring. This compound can be converted to Cembrene by the hydration process [61]. These constituents were not found in the SLab like previous studies.

Previous studies have reported different major components for borage samples. Zribi et al.'s research on three B.officinalis shows benzeneacetaldehyde was the major compound of the essential oils (7.11-9.16\%). Two samples were characterized by the predominance of aldehydes $(27.02 \%$ and $35.16 \%$ ), followed by oxygenated monoterpenes $(20.64 \%$ and $20.58 \%$ ). The essential oils obtained from the third sample showed the predominance of oxygenated monoterpenes $(27.23 \%)$, followed by aldehydes $(23.93 \%)$ and oxygenated sesquiterpenes (12.22\%) [62]. According to Mhamdi et al. study, b-Caryophyllene was the main composition of this species with the highest percentage (26.2\%). Also, after this combination, p-Cymen-8-ol had the highest concentration [63].

Previous evaluations of $\mathrm{E}$. amoenum volatile oil's composition showed that $\alpha$-Cadinene has the highest portion (24.25\%) followed by Hexadecane [64]. Research on E.amoenum petals (yielded $0.05 \%$ ) showed that its major components except aliphatic alkanes, include $\delta$-cadinene (24.25\%), viridiflorol (4.9\%), $\alpha$-muurolene (4.52\%), ledene (3.8\%), $\alpha$-calacorene $(3.04 \%)$, and y-cadinene $(2.9 \%)$ [13].

Also, studies on A. italica indicated that Diisobutyl phthalate (14.6\%), Dibutyl phthalate $(9.0 \%)$, and hexahydro farnesyl acetone (8.1\%) as the major components [65].

By examining the articles related to borage essential oils, similarities between this study's results and other studies were observed. This difference could be due to changes in chemotypes or different chemotypes. On the other hand, some environmental factors, including climate, geographical area, and genetic variations, can cause differences in borage essential oil $[62,66,67]$.

In the present study, in addition to evaluating the composition of essential oils by GC/MS spectrometry, HPTLC was performed to obtain a pattern for borage essential oil samples. All yielded essential oil (S1-S10) were subjected to HPTLC analysis to prepare a TLC profile for comparison (Figure 1). 


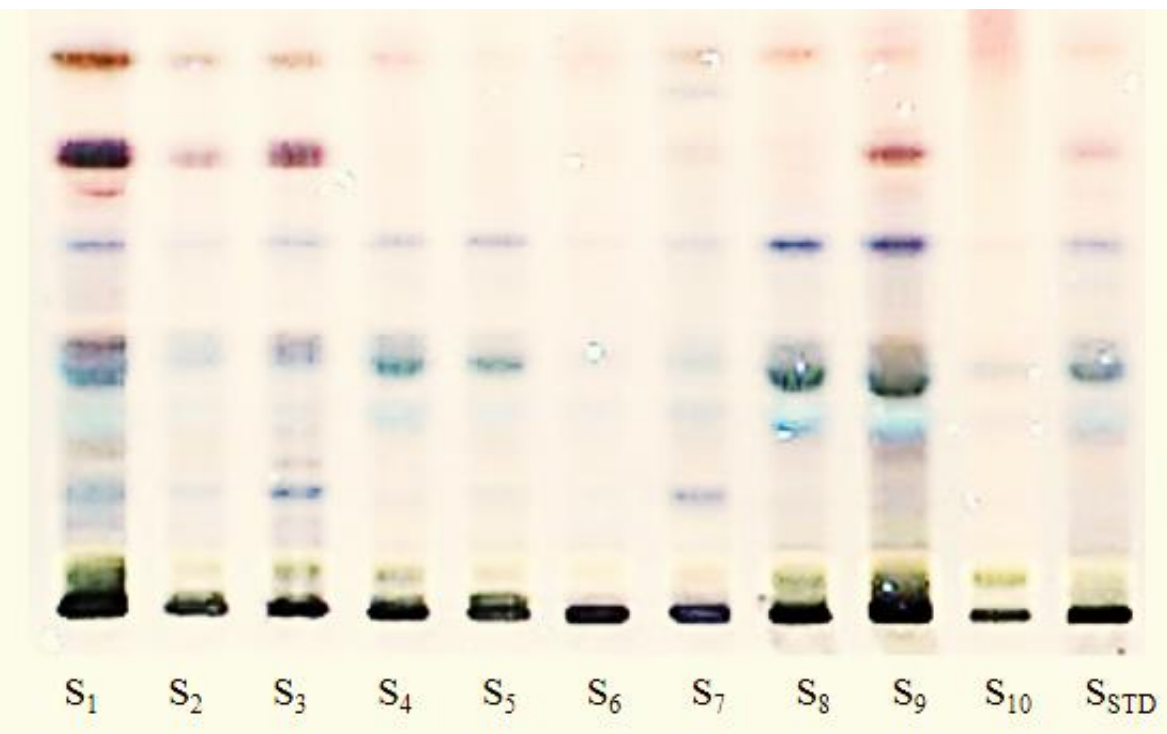

Figure 1. Chromatogram pattern of borage distilled samples from the petroleum ether fraction.

The similarity of the samples' compounds can be seen, although slight differences are observed between the chromatogram spectrum of the essential oil samples. It provides some information about compounds. The chromatogram shows that the existing compounds have significant similarities between the Rf level and the spots' color (Figure 2).

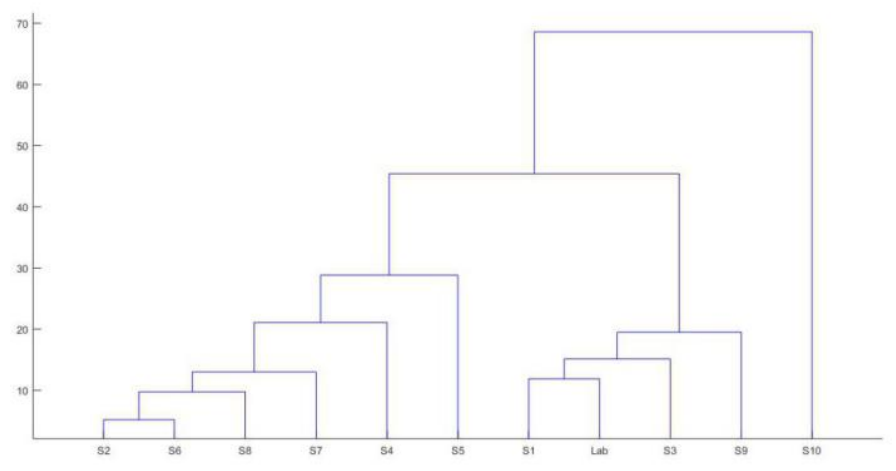

Figure 2. Chromatogram data of analyzed samples.

The GC/MS dendrogram shows that samples one, three, and nine have the most similarity to the SLab sample. Sample 1 in the GC/MS dendrogram is most similar to the standard sample.

Besides, $\mathrm{pH}$ values and conductivity data of all hydrosols are provided in Tables 3 and 4. Regarding $\mathrm{pH}$ and conductivity data, related tables provide this information that all samples were in the range of neutral and weak alkaline.

Table 3. $\mathrm{pH}$ values of hydrosols.

\begin{tabular}{|c|c|c|c|c|c|c|c|c|c|c|c|}
\hline Sample & S1 & S2 & S3 & S4 & S5 & S6 & S7 & S8 & S9 & S10 & $\mathbf{S}_{\text {STD }}$ \\
\hline Mean \pm SD & $7.49 \pm 0.01$ & $7.99 \pm 0.07$ & $\begin{array}{c}7.98 \pm \\
0.01\end{array}$ & $\begin{array}{c}6.86 \pm 0 . \\
05\end{array}$ & $\begin{array}{c}7.40 \pm 0 \\
06\end{array}$ & $\begin{array}{c}7.88 \pm 0 . \\
12\end{array}$ & $\begin{array}{c}7.32 \pm 0 . \\
17\end{array}$ & $\begin{array}{c}7.34 \pm 0 . \\
01\end{array}$ & $\begin{array}{c}7.62 \pm 0 . \\
05\end{array}$ & $\begin{array}{r}7.44 \\
\pm 0.01\end{array}$ & $7.06 \pm 0.02$ \\
\hline
\end{tabular}

Table 4. Conductivity of hydrosols.

\begin{tabular}{|c|c|c|c|c|c|c|c|c|c|c|c|}
\hline Sample & S1 & S2 & S3 & S4 & S5 & S6 & S7 & S8 & S9 & S10 & Lab \\
\hline 1 & 173.7 & 175.05 & 81.6 & 191.8 & 194.5 & 144.1 & 237 & 192.1 & 171.8 & 175.9 & 194.3 \\
\hline 2 & 176.5 & 185.65 & 85.8 & 193.2 & 202.5 & 148.2 & 235.2 & 193.6 & 169.8 & 175.2 & \\
\hline 3 & 170.3 & 182.3 & 78 & 185 & 198.2 & 141.8 & 232.8 & 192.1 & 171.1 & 174.2 & 193.4 \\
\hline
\end{tabular}




\begin{tabular}{c|c|c|c|c|c|c|c|c|c|c|c} 
Sample & S1 & S2 & S3 & S4 & S5 & S6 & S7 & S8 & S9 & S10 & Lab \\
\hline Mean \pm SD & $173.5 \pm 3.1$ & $181 \pm 5.3$ & $81.8 \pm$ & $190 \pm 2$. & $198.4 \pm$ & $144.7 \pm$ & 235 & $192.6 \pm$ & $170.9 \pm$ & 175.1 & $\mathbf{1 9 3 . 6 \pm 0 . 6}$ \\
& & & 3.9 & 5 & 4 & 3.2 & \pm 2.1 & 1 & 1 & \pm 0.8 &
\end{tabular}

\section{Conclusions}

Essential oil extraction and identification with the method mentioned in this study can be introduced as a simple procedure carried out by GC. HPTLC profile of those hydrosols can be mentioned as a simple and efficient method to detect the possible presence of non-related compounds or impurities.

$\alpha$-Humulene, $\alpha$-Pinene, $\alpha$-Cadinol, and Cembrene were the most common compounds in studied samples. Besides, Neocembrene A (22.17\%), trans-Caryophyllene (7.04\%), Dibutyl phthalate $(4.95 \%)$, and Thunbergol $(4.86 \%)$ had the highest mean concentration amount studied samples.

Overall, this study can be considered as a frame for identification, phytochemical assessment, and analysis of volatile constituents in hydrosols distributed in the current market.

\section{Funding}

This research was funded by Shiraz University of Medical Sciences, grant number 8938.

\section{Acknowledgments}

This paper was derived from Azadeh Shiati Pharm.D's thesis. This manuscript's authors wish to express their thanks to Shiraz University of Medical Sciences for financial support (Grant No: 8938).

\section{Conflicts of Interest}

The authors declare no conflict of interest.

\section{References}

1. Andreou, V.; Strati, I.F.; Fotakis, C.; Liouni, M.; Zoumpoulakis, P.; Sinanoglou, V.J. Herbal distillates: A new era of grape marc distillates with enriched antioxidant profile. Food Chem. 2018, 253, 171-178, https://doi.org/10.1016/j.foodchem.2018.01.162.

2. Yousefi, M.; Afshari, R.; Sadeghi, M.; Salari, R. Measurement of Methanol and Ethanol Contents in Most Commonly Used Herbal Distillates Produced by Three Famous Brands. Iran J. Public Health 2018, $47,901$.

3. Valderrama, F.; Ruiz, F. An optimal control approach to steam distillation of essential oils from aromatic plants. Comput. Chem. Eng. 2018, 117, 25-31, https://doi.org/10.1016/j.compchemeng.2018.05.009.

4. Bicchi, C.; Joulain, D. Techniques for preparing essential oils and aromatic extracts. Flavour Fragrance J. 2018, 33, 133-134, https://doi.org/10.1002/ffj.3433.

5. Vazirzadeh, A.; Jalali, S.; Farhadi, A. Antibacterial activity of Oliveria decumbens against Streptococcus iniae in Nile tilapia (Oreochromis niloticus) and its effects on serum and mucosal immunity and antioxidant status. Fish Shellfish Immunol. 2019, 94, 407-416, https://doi.org/10.1016/j.fsi.2019.09.025.

6. Yousefi, M.; Rahimi-Nasrabadi, M.; Pourmortazavi, S.M.; Wysokowski, M.; Jesionowski, T.; Ehrlich, H.; Mirsadeghi, S. Supercritical fluid extraction of essential oils. TrAC, Trends Anal. Chem. 2019, 118, 182193, https://doi.org/10.1016/j.trac.2019.05.038.

7. Alyasin, S.; Maneshian, B.; Tanideh, N.; Miri, R.; Hosseynzadeh, M.; Amin, R.; Ebrahimi, N. The Effect of Platanus orientalis L. Distillate on Mouse Model of Allergic Rhinitis. Iranian Journal of Science and Technology, Transactions A: Science 2020, 44, 21-26, https://doi:.org/0.1007/s40995-019-00813-2.

8. Teymouri, G.S.; Teimouri, M.S. The Comparative Effect of Hydro Alcoholic and Hydro Distillation Extracts of Melissa officinalis on Acne and Pimple. International Journal of Pharmacology. Phytochemistry and Ethnomedicine 2019, 12, 35-43. 
9. López-Hortas, L.; Falqué, E.; Domínguez, H.; Torres, M.D. Microwave hydrodiffusion and gravity versus conventional distillation for Acacia dealbata flowers. Recovery of bioactive extracts for cosmetic purposes. Journal of Cleaner Production 2020, 274, 123143, https://doi.org/10.1016/j.jclepro.2020.123143.

10. Yi, F.; Sun, J.; Bao, X.; Ma, B.; Sun, M. Influence of molecular distillation on antioxidant and antimicrobial activities of rose essential oils. LWT 2019, 102, 310-316, https://doi.org/10.1016/j.lwt.2018.12.051.

11. Gohari, A.; Noorafshan, A.; Akmali, M.; Zamani-Garmsiri, F.; Seghatoleslam, A. Urtica Dioica Distillate Regenerates Pancreatic Beta Cells in Streptozotocin-Induced Diabetic Rats. Iranian Journal of Medical Sciences 2018, 43, 174-183, https://doi.org/:10.30476/ijms.2018.40526.

12. Amanpour, A.; Zannou, O.; Kelebek, H.; Selli, S. Elucidation of Infusion-Induced Changes in the Key Odorants and Aroma Profile of Iranian Endemic Borage (Echium amoenum) Herbal Tea. J. Agric. Food Chem. 2019, 67, 2607-2616, https://doi.org/10.1021/acs.jafc.9b00531.

13. Azizi, H.; Ghafari, S.; Ghods, R.; Shojaii, A.; Salmanian, M.; Ghafarzadeh, J. A review study on pharmacological activities, chemical constituents, and traditional uses of Echium amoenum. Pharmacogn Rev. 2018, 12 .

14. Zakerin, S.; Rezghi, M.; Hajimehdipoor, H.; Ara, L.; Hamzeloo-Moghadam*, M. Antidepressant Effect of a Polyherbal Syrup Based on Iranian Traditional Medicine. Research Journal of Pharmacognosy 2019, 6, 49-56, https://doi.org/10.22127/rjp.2019.84318.

15. Asghari, B.; Mafakheri, S.; Zarrabi, M.M.; Erdem, S.A.; Orhan, I.E.; Bahadori, M.B. Therapeutic target enzymes inhibitory potential, antioxidant activity, and rosmarinic acid content of Echium amoenum. $S$. Afr. J. Bot. 2019, 120, 191-197, https://doi.org/10.1016/j.sajb.2018.05.017.

16. Rabiei, Z.; Setorki, M. Effect of hydroalcoholic Echium amoenum extract on scopolamine-induced learning and memory impairment in rats. Pharm. Biol. 2018, 56, 672-677, https://doi.org/10.1080/13880209.2018.1543330.

17. jafari, h.; Raeis-Abdollahi, E.; Mokaberinejad, R. Echium amoenum from viewpoint of Avicenna: a brief review. Journal of Contemporary Medical Sciences; Vol 4 No 4 (2018): Autumn 20182018.

18. Fakher, S.; Seghatoleslam, A.; Noorafshan, A.; Karbalay-Doust, S.; Rahmanifard, M.; Rashidi, M. The Impact of Echium Amoenum Distillate on Naturally Boosting Fertility: Potential Ameliorative Role in Male Mice Reproductive Parameters. Iranian Journal of Medical Sciences 2019, 44, 227-235, https://doi.org/10.30476/ijms.2019.44978.

19. Torki, A.; Khalaji-Pirbalouty, V.; Lorigooini, Z.; Rafieian-Kopaei, M.; Sadeghimanesh, A.; Rabiei, Z. Anchusa italica extract: phytochemical and neuroprotective evaluation on global cerebral ischemia and reperfusion. Brazilian Journal of Pharmaceutical Sciences 2018, 54.

20. Farahmand, M.; Khalili, D.; Ramezani Tehrani, F.; Amin, G.; Negarandeh, R. Effectiveness of Echium amoenum on premenstrual syndrome: a randomized, double-blind, controlled trial. BMC Complementary Medicine and Therapies 2020, 20, 295, https://doi.org/10.1186/s12906-020-03084-2.

21. Sadeghi, L.; Yousefi Babadi, V.; Tanwir, F. Improving effects of Echium amoenum aqueous extract on rat model of Alzheimer's disease. J. Integra. Neurosci. 2018, 17, 661-669, https://doi.org/10.3233/jin-180093.

22. Majid, A.; Ali, A.M.; Ali, T.; Mahdi, E. Comparing Effectiveness of a Combined Herbal Drug Based on Echium Amoenum with Citalopram in the Treatment of Major Depressive Disorder. Curr. Drug Disc. Technol. 2019, 16, 232-238, http://dx.doi.org/10.2174/1570163815666180219115844.

23. Soltani Nejad, S.; Zeighami, M.; Beirami, A.; Amirifar, A. Effect of Echium Amoenum on the Anxiety of College Students. Complementary Medicine Journal 2020, 10, 46-55.

24. Mozhgan, G.; Atefeh, A.; Nabi, S.; Seyed Hooman, M.; Behrokh Marzban, A.; Saeed, S.; Tahereh, F.; Parisa, S. The Toxicity Effect of Echium amoenum on the Liver and Kidney of Mice. Curr. Drug Disc. Technol. 2020, 17, 1-7, http://dx.doi.org/10.2174/1570163817666200712170922.

25. Mohajer, A.; Araghi, A.; Sadighara, P. Oxidative stress and toxicity effect of Echium amoenum on mice brain. Comp. Clin. Path. 2019, 28, 397-401, https://doi.org/10.1007/s00580-019-02913-2.

26. Avila, C.; Breakspear, I.; Hawrelak, J.; Salmond, S.; Evans, S. A systematic review and quality assessment of case reports of adverse events for borage (Borago officinalis), coltsfoot (Tussilago farfara) and comfrey (Symphytum officinale). Fitoterapia 2020, 142, 104519, https://doi.org/10.1016/j.fitote.2020.104519.

27. Trunz, V.; Lucchetti, M.A.; Bénon, D.; Dorchin, A.; Desurmont, G.A.; Kast, C.; Rasmann, S.; Glauser, G.; Praz, C.J. To bee or not to bee: The 'raison d'être' of toxic secondary compounds in the pollen of Boraginaceae. Funct. Ecol. 2020, 34, 1345-1357, https://doi.org/10.1111/1365-2435.13581.

28. Zamansoltani, F.; Nassiri-Asl, M.; Karimi, R.; Mamaghani-Rad, P. Hepatotoxicity effects of aqueous extract of Echium amoenum in rats. Pharmacologyonline 2008, 1, 432-438.

29. Hamed, A.N.E.; Wahid, A. Hepatoprotective activity of Borago officinalis extract against CCl4-induced hepatotoxicity in rats. J. of Nat. Prod 2015, 8, 113-122.

30. Golmakani, M.-T.; Rezaei, K. Comparison of microwave-assisted hydrodistillation withthe traditional hydrodistillation method in the extractionof essential oils from Thymus vulgaris L. Food Chem. 2008, 109, 925-930, https://doi.org/10.1016/j.foodchem.2007.12.084.

31. Yahya, N.A.; Attan, N.; Wahab, R.A. An overview of cosmeceutically relevant plant extracts and strategies for extraction of plant-based bioactive compounds. Food Bioprod. Process. 2018, 112, 69-85, https://doi.org/10.1016/j.fbp.2018.09.002. 
32. Bayramoglu, B.; Sahin, S.; Sumnu, G. Solvent-free microwave extraction of essential oil from oregano. J. Food Eng. 2008, 88, 535-540, https://doi.org/10.1016/j.jfoodeng.2008.03.015.

33. Hidayah, N.N.; Abidin, S.Z. The evolution of mineral processing in extraction of rare earth elements using solid-liquid extraction over liquid-liquid extraction: A review. Miner. Eng. 2017, 112, 103-113, https://doi.org/10.1016/j.mineng.2017.07.014.

34. Crini, G.; Lichtfouse, E. Advantages and disadvantages of techniques used for wastewater treatment. Environ. Chem. Lett. 2019, 17, 145-155, https://doi.org/10.1007/s10311-018-0785-9.

35. Marsousi, S.; Karimi-Sabet, J.; Moosavian, M.A.; Amini, Y. Liquid-liquid extraction of calcium using ionic liquids in spiral microfluidics. Chem. Eng. J. 2019, 356, 492-505, https://doi.org/10.1016/j.cej.2018.09.030.

36. Adams, R.P. Identification of essential oil components by gas chromatography/mass spectrometry; Allured publishing corporation Carol Stream, IL: 2007; Vol. 456.

37. National Institute of Standards and Technology (NIST). Available online: http://webbook.nist.gov (accessed on 9 October 2020).

38. The Pherobase: Database of Pheromones and Semiochemicals. Available online: https://www.pherobase.com/ (accessed on 9 October 2020).

39. Keawsa-ard, S.; Kongtaweelert, S. Antioxidant, antibacterial, anti-cancer activities and chemical constituents of the essential oil from Mesua ferrea leaves. Chiang Mai J. Sci 2012, 39, 455-463.

40. Legault, J.; Pichette, A. Potentiating effect of $\beta$-caryophyllene on anticancer activity of $\alpha$-humulene, isocaryophyllene and paclitaxel. J. Pharm. Pharmacol. 2007, 59, 1643-1647, https://doi.org/10.1211/jpp.59.12.0005.

41. Damien Dorman, H.J.; Deans, S.G.; Noble, R.C.; Surai, P. Evaluation In Vitro of Plant Essential Oils as Natural Antioxidants. J. Essent. Oil Res. 1995, 7, 645-651, https://doi.org/10.1080/10412905.1995.9700520.

42. Hu, Y.; Zeng, Z.; Wang, B.; Guo, S. Trans-caryophyllene inhibits amyloid $\beta$ (A $\beta$ ) oligomer-induced neuroinflammation in BV-2 microglial cells. Int. Immunopharmacol. 2017, 51, 91-98, https://doi.org/10.1016/j.intimp.2017.07.009.

43. Pinho-da-Silva, L.; Mendes-Maia, P.V.; Teófilo, T.M.d.N.G.; Barbosa, R.; Ceccatto, V.M.; Coelho-deSouza, A.N.; Santos Cruz, J.; Leal-Cardoso, J.H. Trans-caryophyllene, a natural sesquiterpene, causes tracheal smooth muscle relaxation through blockade of voltage-dependent $\mathrm{Ca} 2+$ channels. Molecules 2012, 17, 11965-11977, https://doi.org/10.3390/molecules171011965.

44. Han, L.; Yang, L.; Liu, B.; Cheng, X. Trans-caryophyllene suppresses tumor necrosis factor (TNF $\alpha$ )-induced inflammation in human chondrocytes. Eur. Food Res. Technol. 2014, 239, 1061-1066, https://doi.org/10.1007/s00217-014-2302-0.

45. Liu, H.; Song, Z.; Liao, D.; Zhang, T.; Liu, F.; Zhuang, K.; Luo, K.; Yang, L. Neuroprotective Effects of Trans-Caryophyllene Against Kainic Acid Induced Seizure Activity and Oxidative Stress in Mice. Neurochem. Res. 2015, 40, 118-123, https://doi.org/10.1007/s11064-014-1474-0.

46. Askari, V.R.; Shafiee-Nick, R. Promising neuroprotective effects of $\beta$-caryophyllene against LPS-induced oligodendrocyte toxicity: A mechanistic study. Biochem. Pharmacol. 2019, 159, 154-171, https://doi.org/10.1016/j.bcp.2018.12.001.

47. Yoo, H.-J.; Jwa, S.-K. Inhibitory effects of $\beta$-caryophyllene on Streptococcus mutans biofilm. Arch. Oral Biol. 2018, 88, 42-46.

48. Koyama, S.; Purk, A.; Kaur, M.; Soini, H.A.; Novotny, M.V.; Davis, K.; Kao, C.C.; Matsunami, H.; Mescher, A. Beta-caryophyllene enhances wound healing through multiple routes. PLoS One 2019, 14, e0216104, https://doi.org/10.1371/journal.pone.0216104.

49. Ji, Z.-H.; Zhao, H.; Liu, C.; Yu, X.-Y. In-vitro neuroprotective effect and mechanism of $2 \beta$-hydroxy- $\delta$ cadinol against amyloid $\beta$-induced neuronal apoptosis. Neuroreport 2020, 31.

50. Tung, Y.-T.; Huang, C.-C.; Ho, S.-T.; Kuo, Y.-H.; Lin, C.-C.; Lin, C.-T.; Wu, J.-H. Bioactive Phytochemicals of Leaf Essential Oils of Cinnamomum osmophloeum Prevent Lipopolysaccharide/dGalactosamine (LPS/d-GalN)-Induced Acute Hepatitis in Mice. J. Agric. Food Chem. 2011, 59, 8117-8123, https://doi.org/10.1021/jf2018935.

51. Claeson, P.; Rådström, P.; Sköld, O.; Nilsson, Å.; Höglund, S. Bactericidal effect of the sesquiterpene Tcadinol on Staphylococcus aureus. Phytother. Res. 1992, 6, 94-98, https://doi.org/10.1002/ptr.2650060209.

52. Zygmunt, P.M.; Larsson, B.; Sterner, O.; Vinge, E.; Högestätt, E.D. Calcium Antagonistic Properties of the Sesquiterpene T-Cadinol and Related Substances: Structure-Activity Studies. Pharmacol. Toxicol. 1993, 73, 3-9, https://doi.org/10.1111/j.1600-0773.1993.tb01948.x.

53. Hui, L.-M.; Zhao, G.-D.; Zhao, J.-J. $\delta$-Cadinene inhibits the growth of ovarian cancer cells via caspasedependent apoptosis and cell cycle arrest. Int. J. Clin. Exp. Pathol. 2015, 8, 6046-6056.

54. de Oliveira, J.A.M.; Bernardi, D.I.; Balbinot, R.B.; Cabral, M.R.P.; Zanqueta, É.B.; Endo, E.H.; Dias Filho, B.P.; Nakamura, T.U.; Figueiredo, M.C.; Ruiz, A.L.T.G.; Foglio, M.A.; do Carmo, M.R.B.; Sarragiotto, M.H.; Baldoqui, D.C. New cadinene-sesquiterpene from Chromolaena laevigata (lam.) R. M. King \& H. Rob (Asteraceae) aerial parts and biological activities. Nat. Prod. Res. 2020, 1-8, https://doi.org/10.1080/14786419.2020.1747456. 
55. Pérez-López, A.; Cirio, A.T.; Rivas-Galindo, V.M.; Aranda, R.S.; de Torres, N.W. Activity against Streptococcus pneumoniae of the Essential Oil and $\delta$-Cadinene Isolated from Schinus molle Fruit. J. Essent. Oil Res. 2011, 23, 25-28, https://doi.org/10.1080/10412905.2011.9700477.

56. Guo, X.; Shang, X.; Li, B.; Zhou, X.Z.; Wen, H.; Zhang, J. Acaricidal activities of the essential oil from Rhododendron nivale Hook. $f$. and its main compund, $\delta$-cadinene against Psoroptes cuniculi. Vet. Parasitol. 2017, 236, 51-54, https://doi.org/10.1016/j.vetpar.2017.01.028.

57. Kundu, A.; Saha, S.; Walia, S.; Shakil, N.A.; Kumar, J.; Annapurna, K. Cadinene sesquiterpenes from Eupatorium adenophorum and their antifungal activity. Journal of Environmental Science and Health, Part B 2013, 48, 516-522, https://doi.org/10.1080/03601234.2013.761921.

58. Rodrigues, I.A.; Ramos, A.d.S.; Falcão, D.Q.; Ferreira, J.L.P.; Basso, S.L.; Silva, J.R.d.A.; Amaral, A.C.F. Development of Nanoemulsions to Enhance the Antileishmanial Activity of Copaifera paupera Oleoresins. BioMed Research International 2018, 2018, 9781724, https://doi.org/10.1155/2018/9781724.

59. Turkez, H.; Togar, B.; Tatar, A. Tricyclic sesquiterpene copaene prevents H2O2-induced neurotoxicity. Journal of Complementary Medicine Research 21-28, https://doi.org/10.5455/jice.20131229104710.

60. Turkez, H.; Togar, B.; Tatar, A.; Geyıkoglu, F.; Hacımuftuoglu, A. Cytotoxic and cytogenetic effects of $\alpha-$ copaene on rat neuron and N2a neuroblastoma cell lines. Biologia 2014, 69, 936-942, https://doi.org/10.2478/s11756-014-0393-5.

61. Rassouli, E.; Dadras, O.G.; Bina, E.; Asgarpanah, J. The Essential Oil Composition of Cleome brachycarpa Vahl ex DC. Journal of Essential Oil Bearing Plants 2014, 17, 158-163, https://doi.org/10.1080/0972060X.2014.884784.

62. Zribi, I.; Bleton, J.; Moussa, F.; Abderrabba, M. GC-MS analysis of the volatile profile and the essential oil compositions of Tunisian Borago Officinalis L.: Regional locality and organ dependency. Industrial Crops and Products 2019, 129, 290-298,:https://doi.org/10.1016/j.indcrop.2018.12.021.

63. Mhamdi, B.; Wannes, W.A.; Marzouk, B. Biochemical evaluation of borage (Borago officinalis) rosette leaves through their essential oil and fatty acid composition. Ital. J. Biochem. 2007, 56, 176.

64. Ramaswami, S.K.; Briscese, P.; Gargiullo, R.J.; Von Geldern, T. Sesquiterpene hydrocarbons: from mass confusion to orderly line-up. Developments in food science $\mathbf{1 9 8 8 .}$

65. Kazemi, M. Essential oil composition of Anchusa italica from Iran. Chem. Nat. Compd. 2013, 49, 369-370, https://doi.org/10.1007/s10600-013-0611-3.

66. He, X.; Wang, S.; Shi, J.; Sun, Z.; Lei, Z.; Yin, Z.; Qian, Z.; Tang, H.; Xie, H. Genotypic and environmental effects on the volatile chemotype of Valeriana jatamansi Jones. Frontiers in plant science 2018, 9, 1003, https://doi.org/10.3389/fpls.2018.01003.

67. Miceli, C.; Moncada, A.; Vetrano, F.; Iapichino, G.; D’Anna, F.; Miceli, A. Effect of Agronomic Practices on Yield and Quality of Borage at Harvest and During Storage as Minimally-Processed Produce. Agronomy 2020, 10, 242, https://doi.org/10.3390/agronomy 10020242. 